\title{
NOWOMOWA PSEUDOMETANAUKOWA? O JĘZYKU POLSKIEJ POLITYKI NAUKOWEJ
}

\section{WSTEPP}

Zadaniem językoznawców jest bieżąca refleksja nad językiem. Jako naukowcy i jako humaniści zobligowani sa też do refleksji nad nauka i życiem naukowym. Punktem wspólnym tych obowiązków jest krytyczna obserwacja języka nauki oraz języka dyskusji o nauce.

Głośna w ostatnich latach reforma systemu nauki, której prawny kształt zapisany został w tzw. Ustawie 2.0 (w materiałach MNiSW określanej też mianem Konstytucji dla Nauki $i^{1}$ ), przyniosła ze soba znaczna liczbę tekstów (prawnych, publicystycznych i „eksperckich”). Po raz pierwszy w debacie o organizacji życia naukowego w Polsce $z$ taka intensywnością zastosowano narzędzia PR-u i marketingu politycznego, których ważnym składnikiem jest płaszczyzna leksykalna i tekstowa. Język tego dialogu (często będacego w istocie monologiem) nosi wiele znamion zjawiska tradycyjnie zwanego w polskim językoznawstwie nowomowa, wobec czego wskazane jest podjęcie rozważan nad owa newspeak elit polskiej polityki naukowej.

Kompetencje językoznawcy dotycza sfery języka. Ta jednak pozostaje w oczywistym związku z rzeczywistością pozajęzykową. Krótkie i niezbędne konstatacje odnoszace się do tej ostatniej prezentowałyby się następująco: Ustawa 2.0 nie jest prawem o nauce. Jest przede wszystkim ustawa o strukturach władzy i nowym rozdaniem w polskim „naukowym Monopoly". Opisywane tutaj zachowania językowe pochodza niekiedy od naukowców, którzy o nauce mówią językiem władzy, polityki, perswazji

1 Taka pisownia w materiałach MNiSW. Omawiany akt prawny to w oficjalnej nomenklaturze polskiego systemu prawnego Ustawa $z$ dnia 20 lipca $2018 \mathrm{r}$. Prawo o szkolnictwie wyższym i nauce [Dz.U. 2018, poz. 1668]. Brak tu miejsca na szczegółowe analizy, ale w „przekazie” MNiSW na przestrzeni lat 2016-2018 obserwować można stopniowe odchodzenie od określenia Ustawa 2.0 na rzecz Konstytucja dla Nauki. 
politycznej, a czasem i marketingu. Znamienne jest też, że (omawiane niżej) określenie punktoza wypromowali w znacznej mierze działacze, którzy swoja pozycję ekspercką zbudowali właśnie na kilkuletniej pracy dla ministerialnego „aparatu punktozy”. W ich wypadku punktoza jest nowomownym kreowaniem wroga, którego zwalczanie jest teraz sposobem utrwalania własnej pozycji w gremiach doradczych wpływających na politykę naukowa państwa.

Wyjaśnić wypada od razu, co w niniejszym tekście znaczy nieterminologiczne określenie polityka naukowa. $Z$ jednej strony idzie tu o pewien zespół celów, przekonań, działań i (deklarowanych) wartości kształtujących stanowione przez państwo prawne regulacje uprawiania i - przede wszystkim - ewaluacji nauki, $z$ drugiej zaś o pewna personalna konstelację ludzi polityki i nauki, dla których sterowanie zmiana jest źródłem pozycji i prestiżu. ${ }^{2}$

\section{NOWOMOWA}

W ramach „dyskusji” nad reforma systemu nauki elity polskiej polityki naukowej artykułują swoją wizję zmian, a naukowe „masy” są na ogół jedynie tych komunikatów odbiorca, własne opinie wyrażając ewentualnie $\mathrm{w}$ internetowych komentarzach (a więc w tekstach o niewielkim zasięgu społecznym). Taka sytuacja wyraźnie asymetrycznego przekazu ściśle powiazanego ze strukturami władzy stwarza dogodne warunki do rozwoju niektórych zjawisk typowych dla nowomowy.

Sama nowomowa jest zjawiskiem dość obszernie opisanym w polskim językoznawstwie (i badaniach mu pokrewnych). Wymienić tu należy np. syntetyzujący artykuł J. Sambor ${ }^{3}$ oraz teksty M. Głowińskiego ${ }^{4}$ zebrane w osobnym tomie.

Krytycznie do pojęcia nowomowy podchodzi W. Pisarek, ${ }^{5}$ który $\mathrm{w}$ tym wypadku - podobnie zreszta jak w bardzo wielu innych kwestiach - przyjmuje perspektywę dużo szerszą niż krajowe językoznawcze opi-

2 Taka (wyłaniana na różne sposoby) elita władzy - formalnie lub w sposób niezinstytucjonalizowany - funkcjonować musi zapewne w każdej społeczności. Źle się natomiast dzieje, gdy głoszone przez nią wartości mają charakter wyłącznie instrumentalny.

3 J. Sambor, Nowomowa - język naszych czasów, „Poradnik Językowy” 1985, z. 6, s. 365-377.

${ }^{4}$ M. Głowiński, Nowomowa i ciagi dalsze. Szkice dawne i nowe, Kraków 2009.

5 W. Pisarek, O nowomowie inaczej, „Język Polski” 1993, LXXIII, 1-2, s. 1-9. Na wstępie swego artykułu W. Pisarek [s. 1] przypomina też, że nowomowa jest kalka angielskiego newspeak ukutego przez G. Orwella w Roku 1984. Celem newspeak było „stworzenie języka zdolnego wyrazić światopogląd i oddać w pełni umysłowość właściwą wyznawcom Anglo-Soc i równocześnie - zniweczyć kom- 
nio communis. Słusznie zwraca uwage, że wbrew przekonaniom rozpowszechnionym w polskim piśmiennictwie nowomowa swym zakresem obejmuje nie tylko zachowania językowe polskich władz i mediów komunistycznych okresu 1944-1989, lecz jest pewnym uniwersalnym i ponadczasowym rodzajem użycia języka:

Peerelowska „nowomowa” bowiem była tylko jedną z setek urzeczywistnionych możliwości zastosowania języka w celu perswazyjnym. Od innych zastosowań różniła się głównie cechami przypadkowymi (jedna $z$ nich jest na przykład uprzywilejowanie wzorów języka rosyjskiego jako języka kraju dającego innym „pomoc, przykład, przyjaźn” i zewnętrznymi warunkami jej funkcjonowania (tu należy np. cenzura oraz swoisty system kar i nagród). Natomiast struktury głębokie tych zastosowań języka sa tak stare jak życie społeczne (jeśli chodzi o komunikację publiczna), a nawet tak stare jak sama ludzkość (jeśli chodzi o sferę prywatna). ${ }^{6}$

Dalsze swoje rozważania oprę właśnie na tym poglądzie W. Pisarka, z którego wyprowadzić można wniosek, że nowomowa dzisiejszej polskiej polityki naukowej jest nowym obliczem starych i uniwersalnych zjawisk (czy raczej: typów zachowań) językowych. Nie rezygnuję jednak z przywołanych wyżej ustaleń polskiego językoznawstwa poczynionych w odniesieniu do konkretnej realizacji nowomowy, a więc nowomowy PRL-u. Kategorie i spostrzeżenia obecne w pracach J. Sambor i M. Głowińskiego w znacznej mierze wydają się bowiem trafne także w odniesieniu do języka elit polskiej polityki naukowej lat 2016-2018.

W literaturze ${ }^{7}$ wymienia się zwykle następujące główne cechy PRL-owskiej newspeak:

1) wyraziste, często dychotomiczne wartościowanie, głównie (choć niewyłącznie) jednostek leksykalnych i frazeologizmów, połączone ze skrajna niekiedy redukcja denotacji na rzecz intensywnej konotacji, ${ }^{8}$

2) pragmatyka będaca zakładnikiem rytuału językowego („w pewnych sytuacjach można mówić tak i tylko tak"9),

3) magiczna funkcja mowy; produkowane teksty i tworzone określenia nie opisuja rzeczywistości, ale ją w życzeniowy sposób ustanawiaja,

pletnie możliwość ekspresji dla wszystkich innych sposobów myślenia". Przy okazji newspeak to nazwa tegoż języka w nim samym.

6 Ibidem, s. 8-9.

7 J. Sambor, Nowomowa..., op. cit.; M. Głowiński, Nowomowa..., op. cit., s. 11-33. Artykuł J. Sambor w znacznej części referuje spostrzeżenia zawarte w referatach wygłoszonych na poświęconej nowomowie sesji naukowej, która odbyła się w styczniu 1981 r. na Wydziale Filologicznym UJ.

8 M. Głowiński, Nowomowa..., op. cit., s. 12-13, wyraża to następująco: „Znaczenia moga być niejasne i nieprecyzyjne, oceny zaś - musza być wyraziste i jednoznaczne. W konsekwencji powstaje zjawisko, które określiłbym jako luźną semantykę. Znaczenie zostaje podporządkowane ocenie; czasem nie jest ważne, co dane słowo znaczy, ważne jest zaś, jakie kwalifikatory $z$ nim się wiążą" [wyróżn. - W.W.].

9 Ibidem, s. 13. 
4) arbitralność narzucanych znaczeń (neosemantyzmów) skutkująca rozmyciem i destabilizacja znaczeń wyrazów języka ogólnego / standardowego,

5) zamierzona niedookreśloność, w warstwie leksykalnej obsługiwana m.in. przymiotnikami pewny, określony (por. „pewne rzeczy”, „określone poglądy"),

6) ubóstwo słownictwa.

Ostatni punkt trzeba opatrzyć komentarzem. Ubóstwo słownictwa ma obecnie przypuszczalnie nieco inny (a może właśnie taki sam?) charakter: w marketingu (także politycznym) istotna rolę odgrywają „słowa-sztandary” lub „słowa-symbole”, wyrażające (często mgliście) pozytywne wartości integrujące rządzoną społeczność. Leksykon takich słów musi być ograniczony, by mogły być one rozpoznawalne i skuteczne. We współczesnej nowomowie naukowej dwa najwyższe miejsca na podium zajmuja zapewne doskonałość i prestiż.

\section{JESZCZE O TYTULOWYCH SFORMULOWANIACH}

W. Pisarek ${ }^{10}$ zauważa, że używanie określenia nowomowa samo w sobie jest też zachowaniem nowomownym. Językoznawstwu nie udało się ostatecznie i jednoznacznie określić położenia tego pojęcia względem $\mathrm{w}$ miarę stabilnej siatki pojęć dyscypliny (langue, parole, styl). ${ }^{11}$ Nowomowa nie jest więc pojęciem zdefiniowanym precyzyjnie. Sam „termin” ma konotację negatywną (nowomowa nie może być czymś dobrym). Jego użycie ma jednak w językoznawstwie długa tradycję, dlatego $z$ niego tutaj korzystam.

Wracając do uniwersalnego charakteru zachowań nowomownych, za W. Pisarkiem ${ }^{12}$ należy zwrócić uwagę, że dwa lata przed wydaniem Roku 1984 G. Orwell opublikował esej, w którym krytykuje język polityki w ogóle, określając go mianem political language. Ponieważ przełożenie tego jako język polityczny byłoby cokolwiek niezgrabne, w tytule posługuję się określeniem język polityki (naukowej). Ostatnią sprawą wymagająca wyjaśnienia jest pseudometanaukowy. Język debaty o tzw. reformie Gowina można by było nazwać metanaukowym, gdyby debata ta odbywała się na gruncie „nauki o nauce”. Tak jednak w zdecydowanej większości wypadków nie jest i wszystko zamyka się w sferze naukowego politykowania i pozanaukowej perswazji, a więc pseudometanauki.

10 W. Pisarek, O nowomowie..., op. cit., s. 1.

11 Por. też wątpliwości podnoszone przez M. Głowińskiego, Nowomowa..., op. cit., s. 14-15, który w tym kontekście wymienia pojęcia takie jak: język, mowa, styl, społeczny styl funkcjonalny.

12 W. Pisarek, O nowomowie..., op. cit., s. 2. 


\section{LEKSYKON POLSKIEJ POLITYKI NAUKOWEJ (REKONESANS)}

Ponieważ prymarną właściwością nowomowy jest wartościowanie, omawiany niżej materiał zestawiam tu w podziale na środki konotujące pozytywnie i negatywnie (kursywą wyróżniono nazwy własne; wyrażenia w obu kolumnach nie sa prezentowane jako człony dychotomicznych opozycji). Leksyka i frazeologia języka polskiej polityki naukowej jest oczywiście dużo bogatsza, a omawiane tu wyrażenia wybrano jako reprezentatywne przykłady.

\begin{tabular}{|l|l|}
\hline \multicolumn{1}{|c|}{ konotacja pozytywna } & \multicolumn{1}{c|}{ konotacja negatywna } \\
\hline doskonałość & punktoza \\
Biuro ds. Doskonałości Naukowej PAN & czasopisma drapieżne \\
Rada Doskonałości Naukowej & wydawnictwa drapieżne \\
prestiż & wydawnictwa garażowe \\
dziedziczenie prestiżu & wydać [ksiażkę] u szwagra w garażu \\
wykaz wydawnictw prestiżowych & makulatura \\
slot & leśne dziadki \\
Ustawa 2.O & \\
Konstytucja dla Nauki & \\
Komisja Ewaluacji Nauki & \\
Narodowy Kongres Nauki & \\
\hline
\end{tabular}

\section{DOSKONAEOŚĆ}

Doskonałość idealnie wpisuje się w wyżej nakreślony nowomowny schemat: maksimum konotacji (pozytywne wartościowanie) - minimum znaczenia.

Najprawdopodobniej źródłem omawianego określenia jest angielskie excellence, będące głównym „słowem sloganem" europejskiej polityki naukowej (idzie tu głównie o European Research Council, ERC, które w swoich dokumentach często się do tego określenia odwołuje). ${ }^{13}$ Doskonałość stanowi wyłaczne kryterium oceny wniosków grantowych ERC.

Żeby zilustrować istote problemu związanego $z$ nowomownym wyrazem doskonałość (naukowa), warto przytoczyć wypowiedzi liderów polskiej polityki naukowej. W krótkim wywiadzie $z$ prezesem PAN prof. J. Duszyńskim pada takie pytanie i odpowiedź (tu i niżej wyróżnienia moje):

13 Por. np. stwierdzenie: „Proposals are evaluated by selected international peer reviewers who evaluate proposals on the basis of excellence as the sole criterion" [wyróżn. - W.W.], Starting Grants, https://erc.europa.eu/funding/ starting-grants, dostęp: 02.01.2019. 
[Pytanie:] [słowo niezrozumiałe - dop. W.W.] takiego wydarzenia jak Narodowy Kongres Nauki, cyklicznego już, czy według pana przełoży się to na to, że napłynie do Polski więcej zdolnych naukowców z zagranicy, czy więcej polskich uczonych będzie się ubiegało o granty, czy takie przedsięwzięcia moga się przełożyć na jakieś bardziej wymierne korzyści?

[J.D.:] Ogólnie rzecz biorąc, dyskusja... jest pożyteczna. Ogólnie rzecz biorąc, pojawiają się w tej dyskusji nowe tony. To też jest dobrze. Pewnych rzeczy już nie wypada mówić. Pojawiają się poglądy, które zaczynają dominować i to mnie cieszy, dlatego że $z$ szeregiem takich poglądów ja się zgadzam. To, że jest akcent na doskonałość naukowa, jakby... ...kolwiek na to nie patrzeć, jest bardzo dobrym zjawiskiem i wydaje mi się, że w tej chwili świadomość tego, która wcale nie była taka, pół roku temu, jest bardzo szeroka i ludzie na przykład na tej sesji, która jest za drzwiami, bardzo gruntownie dyskutuja na ten temat. ${ }^{14}$

Przytoczone słowa zapewne nie nosza wszystkich obligatoryjnych cech „klasycznego” machejkizmu, z pewnościa jednak odpowiadaja obecnemu w społecznej świadomości stereotypowemu wyobrażeniu o schemacie wypowiedzi typowym dla wielu przedstawicieli PRL-owskiego aparatu władzy lat 70 . i $80 . \mathrm{XX}$ w.

Dalej w wywiadzie słyszymy:

[Pytanie:] Czy w ciagu tego czasu, od kiedy istnieje... zostało powołane do życia Biuro ds. Doskonałości Naukowej, czy zauważył pan, że jakoś to się może przełożyło na większą liczbę artykułów w prestiżowych czasopismach? Czy coś takiego...

[J.D.:] Nie, nie, bo Biuro do spraw Doskonałości to jest biuro, które ma ułatwiać i zwiększać nasze uczestnictwo w konkursach Europejskiej Rady Nauki. I to jest coś innego niż prestiżowe publikacje. Ale ogólnie rzecz biorac, świadomość, że żeby w ogóle zdobyć takie... stypendia... trzeba dobrze publikować, jest coraz większa i pojawiają się coraz liczniejsze takie [głosy]. ${ }^{15}$

Z kolei w filmiku promocyjnym towarzyszacym jednej z konferencji programowych poprzedzajacych Narodowy Kongres Nauki prof. J. Bujnicki stwierdza: „W kryterium doskonałości naukowej nie chodzi o osiagniecie yyy... perfekcji, tylko o bycie... należenie do czołówki”. ${ }^{16}$ Zaznaczyć trzeba jednak, że przytoczone słowa sa w filmiku jedynie „wstawka” stanowiąca fragment wyjęty $z$ zapewne dłuższej wypowiedzi J. Bujnickiego.

14 Prof. Jerzy Duszyński, Prezes PAN, https://www.youtube.com/watch?v=aPzI2cmpK6g, film opublikowany 23.02.2017, dostęp: 15.04.2017. Szczególną uwage zwraca sformułowanie „Pewnych rzeczy już nie wypada mówić”, które wpisuje się we właściwą nowomowie presupozycję wspólnego systemu wartości omawiana przez J. Sambor, Nowomowa..., op. cit., s. 369-370.

15 Ibidem.

16 https: / / www facebook.com / NarodowyKongres Nauki / videos/1325126990860118/, dostęp: 15.04.2017. Obie cytowane wypowiedzi (J. Duszyńskiego i J. Bujnickiego) są oczywiście jedynie ilustracją opisywanych tendencji. 
Jak zatem w odniesieniu do słowa doskonałość realizuja się w wyżej przytoczonych próbkach typowe cechy nowomowy czasów PRL?

Pierwsza cecha jest oczywiście wartościowanie. $Z$ jednej strony wartościowanie to bierze się $z$ pozytywniej konotacji pierwotnego znaku językowego doskonałość, $z$ drugiej $z$ implicytnego stawiania doskonałości w dobrym świetle (pozytywne wartościowanie wynika $z$ szerszego kontekstu). Druga znamienna właściwościa jest znaczny stopień asemantyczności: pierwsza cytowana wypowiedź J. Duszyńskiego pozbawiona jest właściwie jakiejkolwiek konkretnej treści. Stwierdzenie J. Bujnickiego jest $z$ kolei przykładem zawłaszczania znaków języka ogólnego i arbitralnego modyfikowania ich znaczeń w nowomowie elit. Można by tu podać przegląd definicji słownikowych, wystarczy jednak wskazać, że w słowniku Lindego doskonałość to 'zupełność celności', a doskonały to 'zupełnie taki iaki powinien bydź, bez braku, wady'. W Słowniku języka polskiego pod red. W. Doroszewskiego natomiast doskonałość to 'najwyższy stopień cech dodatnich, brak wad; idealność, wzorowość, świetność'. Dla J. Bujnickiego doskonałość to 'należenie do czołówki', a nie osiagnięcie perfekcji. Swoją droga, metafora oparta na „czołówce” wydaje się tropem wskazującym na postrzeganie nauki jako wyścigu, konkursu i rozgrywki o pozycję w rankingu. Taka doskonałość naukowa niewiele ma wspólnego $z$ doskonałościa obecną w języku ogólnym, oprócz oczywiście tego, że dziedziczy po niej pozytywną konotację.

Arbitralność i zawłaszczanie znaczeń wyraźne są też w utworzonej $z$ wykorzystaniem omawianego słowa sloganu nazwie Biuro ds. Doskonałości Naukowej PAN. Zadaniem tej jednostki jest bowiem wspieranie polskich naukowców w zdobywaniu grantów ERC, które oceniane sa wyłącznie na podstawie kryterium doskonałości (por. przyp. 13.). Taki zakres zadań Biura (skądinąd niezwykle ważnych i potrzebnych) nie ma jednak nic wspólnego $z$ ogólnojęzykowym pojmowaniem doskonałości. Pomysłodawcy omawianej nazwy wyszło coś na kształt Orwellowskiego Ministerstwa Prawdy. W cytowanym wywiadzie pytająca kojarzy doskonałość z prestiżowymi czasopismami. „Słuszne” byłoby natomiast skojarzenie $z$ grantami ERC.

Nowomowna doskonałość przeniknęła też do tekstu ustawy Prawo o szkolnictwie wyższym i nauce [Dz.U. 2018, poz. 1668] w nazwie Rada Doskonałości Naukowej. Instytucja ta jest funkcjonalnym następca Centralnej Komisji, przedmiotem jej działalności nie jest więc doskonałość w sensie ogólnojęzykowym, a głównie prowadzenie procedur awansowych (np. habilitacyjnych). Centralna Komisja ds. Stopni i Tytułów było nazwa neutralna i przejrzysta semantycznie. Rada Doskonałości Naukowej natomiast to kolejne Ministerstwo Prawdy. ${ }^{17}$

17 Te konstatacje dotycza wyłącznie sfery języka, a nie samego przedmiotu: idzie mi tu o niefortunna, "marketingowa” nazwę, a nie o samą instytucję. 
Ciagłe deklinowanie doskonałości jest też chyba dobrym przykładem „magicznej” i „ustanawiajaccej” funkcji nowomowy. Wszechobecne użycie omawianego słowa nie opisuje rzeczywistości. Ono ja tworzy, a w istocie zaklina.

Przywołana ustawa wprowadza ponadto nazwy „programów”: Dydaktyczna inicjatywa doskonałości, Inicjatywa doskonałości-uczelnia badawcza, Regionalna inicjatywa doskonałości. Niżej podpisanemu nie udało się znaleźć w omawianym akcie ustawowej definicji doskonałości.

\section{PRESTIZ்}

Słowem-sztandarem elit polskiej polityki naukowej jest też słowo prestiż. Wiążą się z nim określenia: dziedziczenie prestiżu, wykaz wydawnictw prestiżowych.

Ponieważ w przyszłości czytelnikom trudno będzie zapewne zrozumieć, na czym polegały te rozwiązania, wyjaśniam, że dziedziczenie prestiżu zakłada, iż publikacja naukowa „warta jest tyle”, ile czasopismo lub wydawnictwo, w którym się ukazała. Ile warte jest wydawnictwo (tj. przedsiębiorstwo lub instytucja wydająca książkę) - określa ogłoszony przez ministra nauki wykaz wydawnictw prestiżowych (czyli lista podmiotów, które wydaja prace a priori i de iure uznawane za naukowe i wartościowe). ${ }^{18}$

W wypadku słowa prestiż można by powtórzyć wcześniejsze spostrzeżenia o „luźnej semantyce” i jednoznacznym wartościowaniu. Co ciekawe, w znaczeniu ogólnojęzykowym słownik pod red. W. Doroszewskiego definiuje prestiż jako 'znaczenie, poważanie, wpływ, jakim ktoś lub coś cieszy się w swoim otoczeniu; autorytet, powaga' (wyróżnienie moje), a np. internetowy Słownik języka polskiego PWN zacieśnia definicję do 'poważanie i szacunek, jakim ktoś lub coś cieszy się w swoim otoczeniu'. ${ }^{19}$ Poważania i szacunku nie można ustanowić ani zadekretować. Mimo to działajaccy na UW specjaliści od polityki naukowej stworzyli własna propozycję listy wydawnictw, którą zatytułowali Lista prestiżowych

18 Krytycznie o omawianych rozwiazaniach pisze np. M. Kokowski, Podstawowe zastrzeżenia wobec projektu i uchwalonej Ustawy 2.0 vel Konstytucji dla nauki, „Studia Historiae Scientiarum” 2018, XVII, s. 453-476, który stwierdza [wyróżn. w oryg.]: „(...) jak dobrze wiadomo zawodowym badaczom naukometrii na całym świecie, nie istnieje żadna zasada dziedziczenia prestiżu, zgodnie z która "artykuł jest wart tyle, ile czasopismo, w którym jest opublikowany, a ksiażka jest warta tyle, ile wydawnictwo ją wydające" (...) Natomiast prawda jest, że od lat tak formułowaną zasade dziedziczenia prestiżu promuje lobby właścicieli baz międzynarodowych indeksacyjnych (...) i naukowych wydawnictw biznesowych, które czerpia wielkie zyski z wysoko płatnego modelu "otwartego dostępu" publikacji (...)" [s. 459].

19 Prestiż, https://sjp.pwn.pl/sjp/prestiz;2572402.html, dostęp: 03.01.2019. 
polskich i międzynarodowych wydawnictw naukowych..$^{20}$ Zaryzykować można przypuszczenie, że w odczuciu większości świadomych użytkowników polszczyzny prestiż jest czymś zauważalnym, ale jednocześnie wymyka się ścisłym pomiarom. Tworzenie listy czegoś prestiżowego jest więc nowomownym nadużyciem semantycznym. Nie można jednak przy tym zapominać, że i tutaj dochodzi do głosu „magiczna” funkcja nowomowy, która nie opisuje, a ustanawia rzeczywistość.

\section{KONOTACJE NOWOCZESNEJ TECHNOLOGII}

Uwagę zwrócić trzeba na nieoficjalną, ale swego czasu bardzo promowana „marketingową" nazwę Ustawa 2.0. Numerowanie wersji (często ułamkami dziesiętnymi, stojącymi za nazwa produktu) jest typowe w wypadku oprogramowania komputerowego.

Do technologii komputerowej nawiazuje też slot. Najkrócej rzecz ujmujac, na jednego pracownika jednostki naukowej przypada określona liczba slotów, a więc określona liczba jego publikacji, które uwzględnione będa przy ewaluacji instytucji. Slot (ang. 'otwór; rowek') to tyle, co podłużne gniazdo na płycie głównej komputera, do którego wtyka się karty rozszerzeń albo moduły pamięci RAM. Swoją droga, takie techniczne metafory koresponduja $z$ technokratycznym sposobem myślenia „ekspertów" lobbujacych na rzecz ewaluacji naukometrycznej.

\section{NAZWY WEASNE}

Język polskiej polityki naukowej korzysta $z$ doświadczeń marketingu. Nieschematyczne nazwy ustawy (Konstytucja dla Nauki, Ustawa 2.0) nadaja jej niemalże kształt produktu. Prawo i reforma systemu nauki staja się towarem politycznym na sprzedaż.

Obok nazw „nowoczesnych”, ukuto też jednak nazwy skracające się - niezbyt chyba fortunnie - do postaci literowców historycznych. Gdy pada nazwa KEN, mowa jest wprawdzie o Komisji Ewaluacji Nauki (nazwa obecna w tekście ustawy), choć wykształcony Polak od razu pomyśli o Komisji Edukacji Narodowej. W wypadku NKN (Narodowy Kongres Nauki) skojarzenia $z$ Naczelnym Komitetem Narodowym prawdopodobnie nie były aż tak powszechne, choć wykluczyć ich nie można.

20 Lista prestiżowych polskich $i$ międzynarodowych wydawnictw naukowych, http://bob.uw.edu.pl/wp-content/uploads/sites/72/2018/01/prestizowe_wydawnictwa.pdf, dostęp: 03.01.2019. 


\section{WARTOŚCIOWANIE NEGATYWNE}

Nowomowa pseudometanaukowa jest głównie językiem rozprawiania o przyszłych sukcesach, dysponuje też jednak środkami jednoznacznie negatywnymi. Czasopismo drapieżne ( $\mathrm{z}$ ang. predatory journal) to - $z$ grubsza - periodyk, który pobiera od autorów opłaty za publikację, nie poddając wydawanych artykułów rzetelnemu procesowi recenzyjnemu. O ile czasopismo drapieżne jest tłumaczeniem sformułowania angielskojęzycznego, o tyle wydawnictwo drapieżne jest już raczej „produktem" krajowym, wprowadzonym do obiegu w celu uzasadnienia koncepcji wykazu wydawnictw naukowych. Wykaz ten ma chronić polska naukę przed (nieobecnymi na nim) wydawnictwami garażowymi oraz przed wydawaniem monografii naukowych u szwagra w garażu. Elity polskiej polityki naukowej makulatura nazywaja natomiast artykuły, głównie humanistyczne, opublikowane w czasopismach spoza jednej lub dwóch komercyjnych baz bibliometrycznych.

\section{PUNKTOZA I LEŚNE DZIADKI}

Nowomowa doby PRL-u miała w swoim zasobie leksykę i frazeologię przeznaczona do tworzenia obrazu wroga. Takich zasobów współczesny język polskiej polityki naukowej ma mniej, ale trafiają się przykłady dość spektakularne: punktoza i leśne dziadki.

Punktoza swoja budowa budzi natychmiastowe skojarzenia $z$ nazwami chorób: schorzeń psychicznych ( $p s y c h o z a)$, wad postawy (kifoza, skolioza), schorzeń układu oddechowego (mukowiscydoza), chorób pasożytniczych (ameboza, askarydoza / glistnica, giardioza / lamblioza, leiszmanioza, filarioza), bakteryjnych i grzybiczych (borelioza, mykoza / mikoza) czy chorób skórnych (ichtioza). Zreszta niezależnie od właściwej budowy słowotwórczej wyrazy zakończone na -oza (pomijając część terminologii naukowej, np. laktoza, mejoza, glukoza) predestynowane sa do konotacji negatywnych - por. młodzieżowy wulgaryzm chujoza. $Z$ tego samego modelu skorzystali też naukowcy niechętni systemowi grantowemu, tworząc określenie grantoza.

Istotna cechą określenia punktoza jest swoiste rozdwojenie znaczeń. Znaczenie pierwsze, w którym omawianego wyrażenia używaja „masy”, to tyle, co 'ocenianie dorobku instytucji (a w konsekwencji także indywidualnych dorobków pracowników) na podstawie (niekiedy ustalanych wstecz) wykazów określających, ile punktów otrzymuje praca zależnie od miejsca publikacji (czasopisma lub wydawnictwa)'. W tym właśnie znaczeniu pojawia się punktoza we wstępie niniejszego artykułu („aparat punktozy”). Jest więcej niż oczywiste, że tego rodzaju system punktowy wymusza „rozmienianie nauki na drobne”. Co więcej, jest poważnym zamachem na wolność badań naukowych: reguły ewaluacji podporząd- 
kowuje nie rzeczywistej wartości prowadzonych badań i tradycyjnym ideałom pracy naukowej, lecz wyłącznie urzędniczej wygodzie ewaluatorów, którzy przydzielaja danej instytucji „kategorię naukowa” przekładająca się na wielkość jej budżetu. Tym samym mechanizm dystrybucji państwowych środków na naukę staje się kręgosłupem, sensem i celem krajowego życia naukowego.

Znaczenie drugie określenia punktoza to zaś mniej więcej tyle, co 'zachowania publikacyjne służące maksymalizacji liczby punktów przy minimalizacji wysiłku koniecznego do ich uzyskania'. Przypuszczać można, że znaczeniem pierwotnym było znaczenie pierwsze, a sam nośny neologizm punktoza został następnie zawłaszczony przez ekspertów działajacych w „aparacie punktozy”, dla których nie jest chyba zupełnie oczywiste coś, o czym zachodnia teoria zarządzania wie od dawna: what you measure is what you get. Podsumowujac, punktoza jest ciekawym przypadkiem przejęcia (w drodze neosemantyzacji) przez nowomowę pseudometanaukowa wyrażenia powstałego na gruncie „żargonu reakcyjnego" (zob. niżej). ${ }^{21}$

Leśne dziadki to określenie używane przez zwolenników Ustawy 2.0 w odniesieniu do jej przeciwników, głównie środowisk humanistycznych zgłaszajacych zastrzeżenia pod adresem tego, że reforma dewaluuje badania humanistyczne dotyczace Polski i publikacje wydawane w języku polskim. Samo omawiane określenie nie jest oczywiście innowacja powstała na gruncie nowomowy polskiej polityki naukowej. ${ }^{22}$

\section{1. „ŻARGON REAKCYJNY”}

W reakcji na nowomowę naukowych elit i zderzenie polskiej wspólnoty naukowej $z$ rzeczywistościa ewaluacji naukometrycznej (tj. opartej na liczbie cytowań i najrozmaitszych wartościach pochodnych) w żargonie polskich naukowców pojawiły się m.in. określenia: czasopismo punktowane, czasopismo wysoko punktowane, kudryk.

Czasopismo (wysoko) punktowane jest zapewne żargonowa odpowiedzia na nowomowne czasopismo prestiżowe - wprost wskazuje, że nie chodzi o jakość, a o przypisane punkty.

21 Na temat określenia punktoza zob. T. Szczerbowski, Punktoza jako słowo ostatnich lat, „Poradnik Językowy” 2017, z. 7, s. 80-87 - Red.

22 Nawiasem mówiąc, spośród różnych hipotez na temat genezy tego określenia najbardziej prawdopodobny wydaje się „trop ZBoWiD-owski”. Wikisłownik (opracowanie leksykograficzne, którego w dobie Internetu pomijać nie można) omawiane wyrażenie definiuje następująco: „pot. pejor. starszy wiekiem działacz, polityk, urzędnik lub członek jakiegoś gremium, który uporczywie trwa przy swoich anachronicznych pogladach, hołduje przebrzmiałym zasadom i blokuje awans przedstawicielom młodszego pokolenia", Leśny dziadek, https://pl.wiktionary.org/wiki/le\%C5\%9Bny_dziadek, dostęp: 07.02.2019. 
Punkty, jakie dostawało się za artykuł w czasopiśmie, żargon nazwał prześmiewczo kudrykami (od nazwiska minister Barbary Kudryckiej). Ponieważ reforma Gowina także wprowadza punkty, można się zastanawiać, czy żargon „przeliczy” kudryki na *gowiniaki.

\section{PODSUMOWANIE}

W tytule po nowomowa pseudometanaukowa postawiono znak zapytania. Samo pytanie można by wyrazić zaś następująco: czy język elit polskiej polityki naukowej jest nowomową?

Pobieżna analiza wybranych zachowań mownych i środków językowych pozwala na to pytanie odpowiedzieć twierdzaco, przy czym zastrzec należy, że w nowomowie polskiej elity naukowej potwierdzenie znajduja spostrzeżenia W. Pisarka: nowomowa, język polityki bądź political language to zjawisko uniwersalne i pewien ogólny typ perswazyjnego używania języka jako instrumentu władzy. Tak rozumiana nowomowa może mieć różne realizacje o różnych cechach stricte językowych. W wypadku nowomowy elit polskiej polityki naukowej cechy charakterystyczne w dużym stopniu pokrywaja się $z$ głównymi kategoriami opisu nowomowy PRL, choć oczywiście między jednym a drugim political language nie można stawiać znaku równości.

\section{Pseudo-metascientific newspeak? On the language of the Polish science policy}

\section{Summary}

The aim of this paper is a critical analysis of selected means of the language used in the contemporary (2016-2018) Polish science policy. The analysis attempts to apply the categories developed by Polish researchers in the description of newspeak as the language of power and media at the time of the Polish People's Republic (PRL). The overall discussion is based on W. Pisarek's view that what is called newspeak and referred to the PRL period in the Polish literature is in fact one of many possible forms of using language as an instrument of political persuasion.

The object of the description is mainly language behaviours of the Polish scientists who are powerful and influential in the world of Polish science and who co-decide on the governmental science policy. The focus is on the language of the debate on a reform of the system of science and higher education (the so-called Ustawa 2.0 (Act 2.0), Konstytucja dla Nauki (Constitution for Science), ustawa Gowina (Gowin's Act)). 
The principal conclusion is that the apparatus developed in the description of the newspeak of the PRL period could be employed in the description of a large number of language behaviours of representatives of the Polish science policy of the end of the $2^{\text {nd }}$ decade of the $21^{\text {st }} \mathrm{c}$. The flag words of the Polish science policy are characterised by monovalent connotation combined with a vague (or no) denotation.

Trans. Monika Czarnecka 